\title{
Introduction
}

\section{European Jesuits in China: The Importance of the Jesuits for the Cultural and Scientific Devel- opment of European and Chinese Society}

\section{Nataša VAMPELJ SUHADOLNIK}

It is my great privilege and pleasure to introduce the present issue of the journal Asian Studies. This is a special issue devoted to the topic of European Jesuits in China, and it is dedicated to Professor Mitja Saje and his academic and scientific research work. Professor Saje is one of the three co-founders of the Department of Asian Studies (formerly Asian and African Studies), which was established at the University of Ljubljana in 1995. Until his retirement (July 2015), he was a constant presence in the Department and one of its guiding spirits over the last twenty years. Possessed of an enormous respect for Chinese culture, he contributed significantly not only to the academic development of the Department, but also to promoting that culture in Slovenia as a whole. Professor Saje is specialised in traditional and modern Chinese history, politics and economy. His four volume study of Chinese history is the most comprehensive and important work of its kind in the Slovenian language. It is, in fact, a pioneering work in Slovenian sinology, and provides both a chronological exposition of this complex subject from the earliest times to the founding of the People's Republic of China, as well as thorough and penetrating analyses of the many socio-political factors which influenced the development of Chinese society.

In addition to this major historical work, a significant part of Professor Saje's academic activity was also dedicated to researching the Jesuit community in Beijing and, in particular, to the forgotten "Slovenian" Jesuit missionary, Ferdinand $\mathrm{Au}$ gustin Hallerstein (1703-1774) (Chinese name Liu Songling 劉松齡). Hallerstein was an active member of the Qianlong 乾隆 (1711-1799) court and was appointed Head of the Imperial Board of Astronomy in 1747, a position he would maintain until his death nearly 30 years later. Professor Saje was one of the first Slovenian scholars to underscore the importance of Hallerstein's life and work, and

Nataša VAMPELJ SUHADOLNIK, Associate Professor, Department of Asian Studies, Faculty of Arts, University of Ljubljana, Slovenia. natasa.vampeljsuhadolnik@ff.uni-lj.si

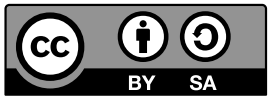


promote the study of this figure within both the European and Chinese academic communities. He was the editor and main instigator for the first comprehensive monograph on Hallerstein in English, A. Hallerstein - Liu Songling: The Multicultural Legacy of Jesuit Wisdom and Piety at the Qing Dynasty Court, published in Maribor in 2009. This study provides the broader academic community with an innovative approach to the cultural links between China and Europe and offers new material regarding Hallerstein's scientific, religious, diplomatic, and cultural activities and writings. The monograph is especially valuable because it includes the English translation of most of his letters (with only the purely scientific correspondence excluded), which were addressed to fellow Jesuits in Europe, family members and even the Queen of Portugal, Maria Anna (1683-1754).

In recognition of Professor Mitja Saje's achievements in this research area, the present issue is dedicated to the European Jesuit missionaries in China from the 17 th and 18th centuries, and their major contributions to the cultural and scientific development of European and Chinese society. It brings together a select group of papers that analyse diverse aspects of the work of the Jesuits in China, especially the mathematicians, scientists, and cultural envoys from Central and Eastern Europe who succeeded in establishing early scientific and cultural links between the West and China. While most of these missionaries came from different regions of the Habsburg Monarchy, their ethnic and geographical origins had little meaning for the Chinese. With the dissolution of Austro-Hungarian Empire after World War I, some of the more prominent Jesuits were forgotten by the new countries which had been established on the ruins of the Empire. In our view, sinologists and historians in Central and East European countries have a duty to underscore the cultural and scientific importance of these early missionaries and to reaffirm their historic role. The Chinese should likewise do more to recognise and link these figures with their countries of origin. Ultimately, the achievements of these missionaries belong both to their countries of origin and to China, where they lived and worked, and to which they dedicated much of their lives and knowledge.

The volume opens with a section dedicated to the "Slovenian" Jesuit, Ferdinand Augustin Hallerstein, who due to various historical and political circumstances was forgotten for more than 200 years. The rediscovery of Hallerstein began with a number of cooperation projects between the Slovenian and Chinese archives in the 1980s. In 1985, to mark the 210th anniversary of his death, Professor Ju Deyuan published an article in the Palace Museum Journal entitled: Liu Songling, Head of the Imperial Board of Astronomy in the Qing Dynasty. The revival of interest in Hallerstein in Slovenia instead began with the work of Zmago Šmitek, Professor of cultural anthropology and ethnology at the University of Ljubljana, who 
included chapters on Hallerstein in his two volume work dedicated to famous Slovenian travellers (Šmitek 1986 and Šmitek 1995). New impetus arrived with the symposium held in Ljubljana to mark the 300th anniversary of Hallerstein's birth. As part of this event, the Mengeš museum unveiled a bronze plaque at his birthplace. The symposium resulted in two monographs: one dedicated to his achievements as an astronomer (Južnič 2003) and the second to his scientific and cultural work in general which also included the first translations of Hallerstein's letters into Slovenian (Hribar 2003). Hallerstein's life and role as a cultural bridge between Europe and China next became the focus of a two-year European Union project (2007-2009). The project not only greatly accelerated the scholarly research, but also supported the artistic promotion of Hallerstein in several European countries and China, culminating in seven performances which combined historical documentation with contemporary performing arts and new media technologies. Of the various international symposiums and conferences which have taken place since then, the most important was the international symposium in Beijing in 2009, which provided a platform for discussing Hallerstein's role in China, and brought together a wide range of Chinese scholars from different research institutions. ${ }^{1}$ The intense research on Hallerstein over the last two decades has brought to light numerous documents, scientific reports and letters, which were scattered among many different European archives (in Austria, Italy and the Vatican, Portugal, Russia, France, England, Belgium, and Slovenia). Much of this new material was collected in the first comprehensive monograph in English, $A$. Hallerstein - Liu Songling: The Multicultural Legacy of Jesuit Wisdom and Piety at the Qing Dynasty Court, edited by Professor Mitja Saje.

The first section thus provides new insights into Hallerstein's life and work in Beijing, based on the materials in various Chinese and European archives and on his correspondence. The first article, by Mitja Saje, investigates the importance of Hallerstein for European cultural and political relations with China and Korea. While his work in China is well known, his cultural link with Korea has yet to be fully examined. Based on new documentation, the author confirms Hallerstein's strong relations with Korean scholars and highlights his role as an important cultural link not only between China and Slovenia, but also between Korea and Slovenia. The second article, by Nataša Vampelj Suhadolnik, examines Hallerstein's correspondence, and especially his relationship with the celebrated Jesuit painter, Giuseppe Castiglione (1688-1766). The article is the first to analyse Hallerstein's views on the famous Jesuit painter and offers original insights into court painting and Castiglione's art, together with new evidence regarding the painter's works.

1 The symposium, entitled "Early European Missionaries in China and Sinological Studies", was held at the Beijing University of Language and Culture, September 2009. See also Saje 2009, 46-47. 
The second section, entitled European Jesuits as a Cultural Bridge between China and Europe, consists of articles by Vladimír Liščák (Oriental Institute of the Czech Academy of Sciences, Prague) and Xiangyan Jiang (East China Normal University). Liščák discusses one of eight Jesuits from the original province of Bohemia, Karel Slavíček (1678-1735), who came to China in 1716. Even though he was a gifted mathematician, astronomer, and cartographer, as well as a talented musician whose abilities were much prized by the Emperor, like Hallerstein his name rarely appears in general Chinese histories or in studies of Christianity in China. The author analyses Slavíček's letters, which first appeared in a Czech edition in 1995, followed by a Chinese translation a few years later (Beijing 2002), and provides a detailed catalogue of his correspondence. Xiangyan Jiang instead addresses the issue of Christian terminology in the French translation of the eight poems selected from the Greater Odes, Minor Odes and Sacrificial Odes of Zhou of the Book of Poetry, which were translated into French by the French Jesuit missionary, Joseph de Prémare (1660-1736) in the early 18th century. By analysing Prémare's translation of the key concepts—Tian 天, Haotian 昊天 and Shangdi 上帝—Jiang reveals their theological significance in terms of Christianity, and examines the correspondences that Prémare draws between the two religious and cultural systems in his translation.

In the third and final section, entitled Scientific and Astronomic Achievements of European Jesuits, Stanislav Južnič (University of Oklahoma) and Fuxiang Guo (Palace Museum in Beijing) discuss the work of Jesuit scientists and astronomers in China. While the primary aim of the Jesuits in China was spreading Christianity, due to their advanced knowledge of astronomy, mathematics, and geography they were highly esteemed by the Chinese emperors, who entrusted them with important scientific projects, such as revising the calendar, observing astronomical phenomena, and constructing astronomical and other scientific instruments, and also appointed them to key positions on the Imperial Board of Astronomy. Based on important new documentation regarding Central European Jesuits, Stanislav Južnič provides a detailed study of nine Austrian Jesuits who lived and worked in China in the 17th and 18th centuries. The author also analyses statistical data regarding Central European Jesuits, and focuses on their role in the exchange of religious, philosophical, cultural and even economic notions between Europe and China. The article concludes by examining the contribution of the Jesuits to the economic, military and political development of modern Chinese society. This special thematic issue concludes with an article in Chinese by Fuxiang Guo, researcher and curator from the Palace Museum in Beijing. Based on the vast collection of western scientific instruments housed at the Palace Museum in Beijing, Guo's article examines the material and cultural heritage of the Jesuits in China. 
Based on archival data and other documentation, as well as the Museum's physical collections, the author discusses the classification and typology of the various instruments, and describes the origins and history of the collection, which had three primary sources: foreign diplomatic gifts, contributions of the missionaries and other officials, and court officials and artisans who manufactured the instruments at the court.

The present collection of articles deals primarily with new and previously unpublished material regarding the scientific and cultural work of the European Jesuits in China from the 17th and 18th centuries. It thus offers new insights into the highly diversified activities of the Jesuits and their impact on the cultural and scientific development of both European and Chinese societies, an influence which is still evident today. We hope this special issue will contribute to a more profound understanding of the achievements of the Jesuit missionaries and, in particular, of their influence on the increased flow of intellectual and material goods in today's globalisation process and on the future development of modern and contemporary factors and issues related to China and Europe. Seeking to understand events through a broader global perspective is the key to greater mutual understanding among peoples and cultures.

We hope our readers will enjoy this issue.

Nataša Vampelj Suhadolnik, Guest Editor

\section{References}

Hribar, Viljem Marjan, ed. 2003. Mandarin: Hallerstein, Kranjec na kitajskem dvoru. Radovljica: Didakta.

Južnič, Stanislav. 2003. Kitajski astronom iz Mengša. Ljubljana: Tehniška založba. Šmitek, Zmago. 1986. Klic daljnib svetov. Radovljica: Didakta.

—. 1995. Srečevanja z drugačnostjo: slovenska izkustva eksotike. Radovljica: Didakta. 